\title{
Broad-Spectrum Antiviral Natural Products from the Marine-Derived Penicillium sp. IMB17-046
}

\author{
Jiao Li ${ }^{1,+}$, Yujia Wang ${ }^{1,+}$, Xiaomeng Hao ${ }^{1}$, Shasha Li $^{1}$, Jia Jia ${ }^{2}$, Yan Guan ${ }^{1}$, Zonggen Peng ${ }^{1}$, \\ Hongkai Bi ${ }^{2}$, Chunling Xiao ${ }^{1}$, Shan Cen ${ }^{1}$ (D) and Maoluo Gan ${ }^{1}$ * (D) \\ 1 Institute of Medicinal Biotechnology, Chinese Academy of Medical Sciences and Peking Union Medical \\ College, Beijing 100050, China \\ 2 Department of Pathogen Biology, Jiangsu Key Laboratory of Pathogen Biology, Nanjing Medical University, \\ Nanjing 210029, China \\ * Correspondence: ganml@imb.pumc.edu.cn; Tel.: +86-10-63165277 \\ + These authors contributed equally to this work.
}

Academic Editors: Francisco (Paco) Barona-Gomez, Cuauhtemoc Licona-Cassani and

Corina Diana Ceapă

Received: 16 July 2019; Accepted: 31 July 2019; Published: 2 August 2019

check for updates

\begin{abstract}
A new pyrazine derivative, trypilepyrazinol (1), a new $\alpha$-pyrone polyketide, (+)-neocitreoviridin (2), and a new ergostane analogue, 3 $\beta$-hydroxyergosta-8,14,24(28)-trien-7-one (3), were isolated and characterized along with five known compounds from the marine-derived fungus Penicillium sp. IMB17-046. The structures of these new compounds were determined using spectroscopic data analyses (HRESIMS, 1D- and 2D-NMR), X-ray crystallography analysis, and TDDFT ECD calculation. Compounds $\mathbf{1}$ and $\mathbf{3}$ exhibited broad-spectrum antiviral activities against different types of viruses, including human immunodeficiency virus (HIV), hepatitis $C$ virus $(\mathrm{HCV})$, and influenza A virus (IAV), with $\mathrm{IC}_{50}$ values ranging from 0.5 to $7.7 \mu \mathrm{M}$. Compounds 1 and $\mathbf{2}$ showed antibacterial activities against Helicobacter pylori, a causative pathogen of various gastric diseases, with minimum inhibitory concentration (MIC) values of $1-16 \mu \mathrm{g} / \mathrm{mL}$.
\end{abstract}

Keywords: marine fungus; Penicillium; pyrazine natural product; antiviral; HIV; influenza A virus; Helicobacter pylori

\section{Introduction}

Viruses such as the human immunodeficiency virus (HIV), influenza virus, and hepatitis B and $\mathrm{C}$ viruses (HBV and $\mathrm{HCV}$ ) are great global threats to public health. According to the recent World Health Organization (WHO) reports, 36.7 million people were living with HIV in 2015, among which approximately 2.7 million and 2.3 million had a chronic HBV and HCV coinfection, respectively [1,2]. It is estimated that hepatitis viruses caused 1.34 million deaths in 2015 while influenza viruses are responsible for 250,000 to 500,000 death globally every year. Despite the great achievements made in antiviral drug discovery during the past 50 years, there is still no effective antiviral drug for over 200 infectious diseases [2]. The increasing emergence of drug-resistant viral strains urgently requires the development of new antiviral drugs with novel action mechanisms. Particularly, broad-spectrum antiviral drugs are needed to combat multiple viral infectious diseases since most of the current antiviral drugs are effective to only certain viral strains [2].

Marine fungi are prolific sources of new structurally diverse compounds, and have yielded more than 1000 new metabolites, many of them displaying interesting biological activities, such as antibacterial, antifungal, antiviral, cytotoxic, and antiprotozoal properties [3,4]. During our ongoing program screening for new bioactive natural products from marine-derived microorganisms [5-9], the extracts from the solid cultures of the marine-derived strain Penicillium sp. IMB17-046 were shown to 
possess inhibitory activity against HIV-1 replication and antibacterial activities against Gram-negative bacteria. Further chemical investigation of the extracts led to the identification of a new pyrazine congener, trypilepyrazinol (1), a new $\alpha$-pyrone polyketide, (+)-neocitreoviridin (2), and a new ergostane-type sterol, $3 \beta$-hydroxyergosta-8,14,24(28)-trien-7-one (3), together with the known epiisocitreoviridinol

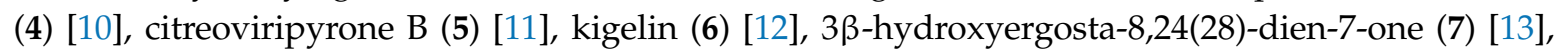
and (22E,24R)-24-methyl-5 $\alpha$-cholesta-7,22-dien-3 $\beta, 5,6 \beta$-triol (8) [14] (Figure 1). Herein, we describe the isolation, structural elucidation, and antiviral and antibacterial properties of the new compounds.

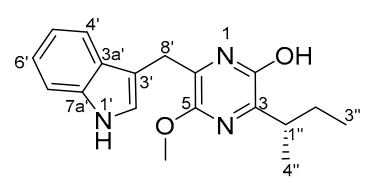

1
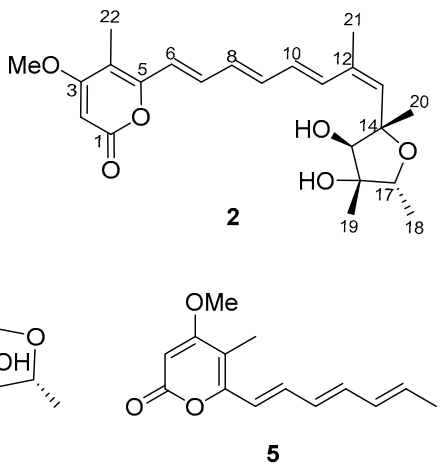
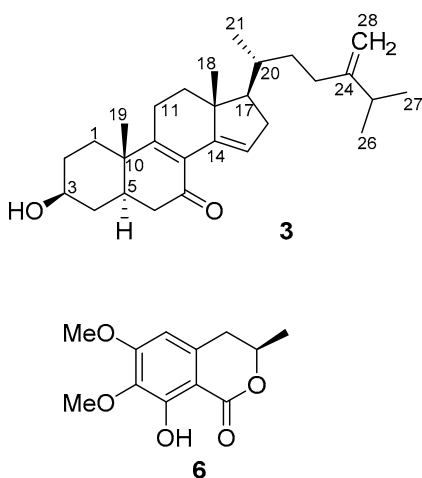

4

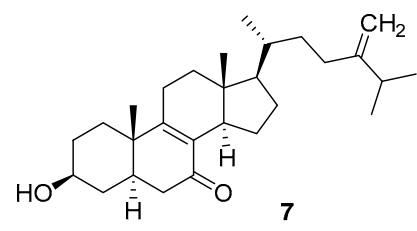

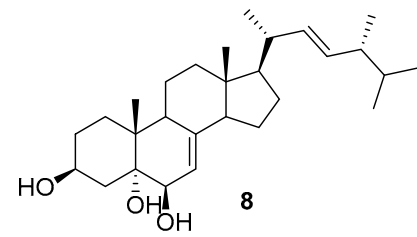

Figure 1. Structures of compounds 1-8 from Penicillium sp. IMB17-046.

\section{Results and Discussion}

Compound 1 was isolated as a colorless plate crystal. Its molecular formula was determined to be $\mathrm{C}_{18} \mathrm{H}_{21} \mathrm{~N}_{3} \mathrm{O}_{2}$ by HRESIMS, indicating 10 degrees of unsaturation. The IR spectrum showed the presence of the hydroxy or amino $\left(3421 \mathrm{~cm}^{-1}\right)$ and the aromatic ring $\left(1615 \mathrm{~cm}^{-1}\right)$ groups. The ${ }^{1} \mathrm{H}-\mathrm{NMR}$ spectrum in $\mathrm{CDCl}_{3}$ (Table 1) revealed three methyl signals comprising a methoxy $\left(\delta_{\mathrm{H}} 3.98\right)$ and two aliphatic methyls $\left(\delta_{\mathrm{H}} 1.20, \mathrm{~d} ; 0.87, \mathrm{t}\right)$, two methylenes $\left(\delta_{\mathrm{H}} 4.13 / 4.10 ; 1.81 / 1.55\right)$, a methine $\left(\delta_{\mathrm{H}} 3.15\right)$, four protons between $\delta_{\mathrm{H}} 7.09$ and 7.68 ascribed to an ortho-disubstituted aromatic ring, an isolated olefinic proton $\left(\delta_{\mathrm{H}} 7.22\right)$, as well as an exchangeable proton $\left(\delta_{\mathrm{H}} 8.04, \mathrm{H}-1^{\prime}\right)$. The ${ }^{13} \mathrm{C}-\mathrm{NMR}$ and DEPT spectra showed 18 carbon signals, including three methyls, two methylenes, five $\mathrm{sp}^{2}$ one aliphatic methine, and seven non-protonated $\mathrm{sp}^{2}$ carbons. The COSY correlations of $\mathrm{H}-4^{\prime} / \mathrm{H}-5^{\prime} / \mathrm{H}-6^{\prime} / \mathrm{H}-7^{\prime}$ and $\mathrm{H}_{3}-4^{\prime \prime} / \mathrm{H}-1^{\prime \prime} / \mathrm{H}-2^{\prime \prime} \mathrm{a} / \mathrm{H}-2^{\prime \prime} \mathrm{b} / \mathrm{H}_{3}-3^{\prime \prime}$ confirmed the presence of the ortho-disubstituted aromatic ring and a sec-butyl fragment (Figure $2 \mathrm{a}$ ). The HMBC cross-peaks of $\mathrm{H}_{2}-8^{\prime}$ with $\mathrm{C}-2^{\prime}, \mathrm{C}-3^{\prime}$, and C-3a' $\mathrm{NH}^{\prime} \mathrm{1}^{\prime}$ with $\mathrm{C}-3^{\prime}, \mathrm{C}-\mathrm{7}^{\prime}$, and $\mathrm{C}-7 \mathrm{a}^{\prime}$; and $\mathrm{H}-4^{\prime}$ with $\mathrm{C}-3^{\prime}$ and $\mathrm{C}-3 \mathrm{a}^{\prime}$ suggested that the aromatic ring was present as an (indole-3-yl)methyl unit. In the ${ }^{13} \mathrm{C}-\mathrm{NMR}$ spectrum, four unassigned quaternary carbons resonated at $\delta_{C} 153.3,149.8,148.7$, and 128.7. In addition, the remaining atoms required by the molecular formula included a hydrogen, an oxygen, and two nitrogens. By taking into consideration the unsaturation requirement, these data suggested the presence of a pyrazine ring in the molecule $[15,16]$. The HMBC correlations of $\mathrm{H}-1^{\prime \prime}$ with the carbons at $\delta_{\mathrm{C}} 153.3$ (C-2) and 149.8 (C-3) along with the correlation of $\mathrm{H}-4^{\prime \prime}$ with the carbon at $\delta_{\mathrm{C}} 149.8$ (C-3) located the sec-butyl at C-3 of the pyrazine ring. The HMBC correlations of $\mathrm{H}_{2}-8^{\prime}$ with the carbons at $\delta_{\mathrm{C}} 128.7$ and $\delta_{\mathrm{C}} 148.7$ along with the correlation of the methoxy protons $\left(\delta_{\mathrm{H}} 3.98\right)$ with the carbon at $\delta_{\mathrm{C}} 148.7$ suggested that the (indole-3-yl)methyl unit and the methoxy group were attached to the carbons at $\delta_{C} 128.7$ and $\delta_{C} 148.7$, respectively. However, these correlations did not allow for distinction of 2,5- versus 2,6-dioxy substitutions and thus could not define the location of the methoxy group (C-5 or C-6). Furthermore, it was not possible to determine whether the C-2 of the pyrazine ring was enolized based on the NMR data $[15,16]$. Therefore, compound 1 was 
subjected to X-ray crystallographic analysis using $\mathrm{Cu} \mathrm{K} \alpha$ radiation (Figure $2 \mathrm{~b}$ ), which unambiguously established the structure as $\mathbf{1}$ with an enol group at C-2. The small values of the Flack parameter 0.02 (8) [17] and the Hooft parameter 0.04 (7) [18] in the final refinement of the crystallographic data allowed for assignment of the absolute configuration of $\mathbf{1}$ as $1^{\prime \prime} S$. Therefore, the structure of 1 was determined as (S)-6-((1H-indol-3-yl)methyl)-3-(sec-butyl)-5-methoxypyrazin-2-ol. According to the proposed biosynthetic pathway for natural pyrazines $[19,20]$, compound 1 was probably derived from the precursors tryptophan and isoleucine and was thereby assigned the trivial name trypilepyrazinol.

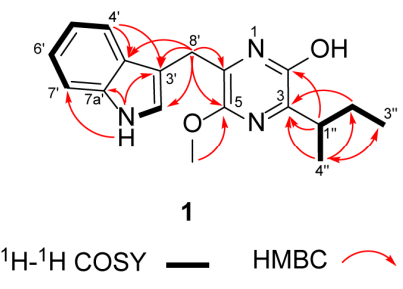

(a)

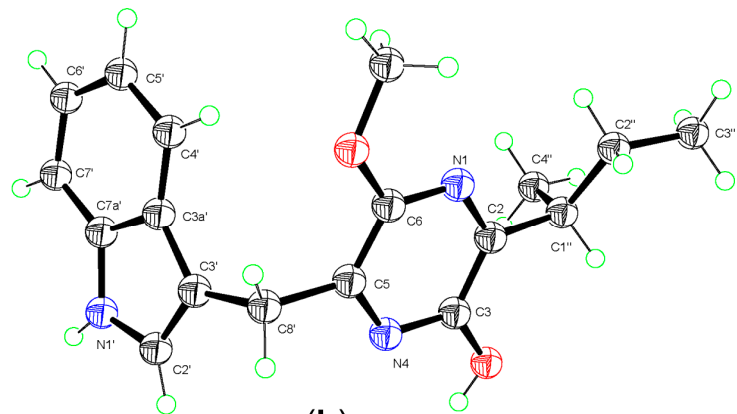

(b)

Figure 2. (a) The ${ }^{1} \mathrm{H}-{ }^{1} \mathrm{H}$ COSY and key HMBC correlations of $\mathbf{1}$. (b) X-ray crystallographic structure of $\mathbf{1}$.

Table 1. NMR spectroscopic data for compounds $1-3$ in $\mathrm{CDCl}_{3} \cdot{ }^{\mathrm{a}}$

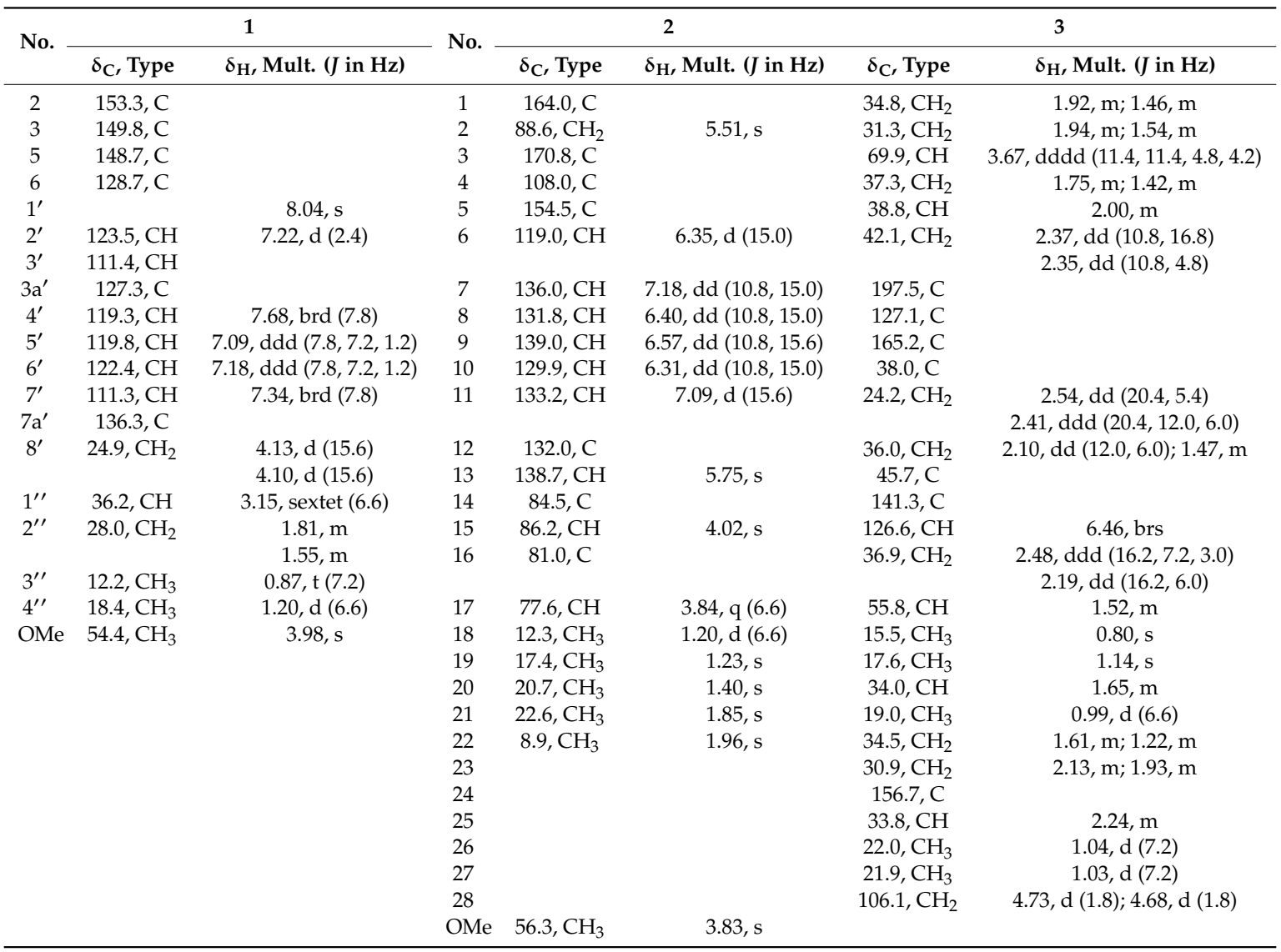

${ }^{\text {a }}$ The assignments were based on $2 \mathrm{D}-\mathrm{NMR}\left({ }^{1} \mathrm{H}-{ }^{1} \mathrm{H}\right.$ COSY, HSQC, and HMBC) experiments.

Compound 2 was obtained as yellow needles with a molecular formula $\mathrm{C}_{23} \mathrm{H}_{30} \mathrm{O}_{6}$ as suggested by HRESIMS. The ${ }^{1} \mathrm{H}-\mathrm{NMR}$ spectrum of 2 displayed the signals for six coupled olefinic protons at $\delta_{\mathrm{H}}$ 6.35-7.18, two isolated olefinic proton singlets at $\delta_{\mathrm{H}} 5.51(\mathrm{H}-2)$ and $5.75(\mathrm{H}-13)$, two oxygenated methine protons at $\delta_{\mathrm{H}} 4.02(\mathrm{~s}, \mathrm{H}-15)$ and 3,84 (q, H-17), five methyls at $\delta_{\mathrm{H}} 1.20-1.96$, and a methoxy 
group at $\delta_{\mathrm{H}} 3.83$ (Table 1). The ${ }^{13} \mathrm{C}-\mathrm{NMR}$ and DEPT spectra in $\mathrm{CDCl}_{3}$ showed the presence of one ester carbonyl, four nonprotonated $\mathrm{sp}^{2}$, and two nonprotonated oxygen-bearing $\mathrm{sp}^{3}$ carbons in addition to the methyl and methine signals mentioned above. The molecular formula, UV, and NMR data of 2 were similar to those of citreoviridin obtained from Aspergillus terreus [21] and other Penicillium strains (Table S1) $[11,22,23]$. Interestingly, compound 2 has a positive optical rotation $\left([\alpha]_{D}^{20}+67.3\right.$ in $\mathrm{MeOH})$, opposite to that of citreoviridin $\left([\alpha]_{\mathrm{D}}^{20}-105\right.$ in $\mathrm{MeOH}$ and -107.8 in $\left.\mathrm{CHCl}_{3}\right)$ [24,25]. In addition, the resonances for $\mathrm{H}-11$ and $\mathrm{C}-21$ in 2 were deshielded by $\Delta \delta_{\mathrm{H}}+0.77$ and $\Delta \delta_{\mathrm{C}}+9.2 \mathrm{ppm}$, respectively, in comparison with those of citreoviridin recorded in $\mathrm{CDCl}_{3}$, whereas $\mathrm{H}-13, \mathrm{H}_{3}-21, \mathrm{C}-11$, and $\mathrm{C}-13$ in 2 were shielded by $\Delta \delta_{\mathrm{H}}-0.16$ and -0.08 and $\Delta \delta_{\mathrm{C}}-7.5$ and $-2.3 \mathrm{ppm}$, respectively, indicating that compound 2 was the $\Delta^{12(13)}$ geometrical isomer of citreoviridin. The ROESY correlations of $\mathrm{H}-13 / \mathrm{H}_{3}-21$ and $\mathrm{H}-11 / \mathrm{H}-15$ confirmed the Z-geometry of the 12,13-double bond (Figure 3). The geometries for other double bonds were established as $E$, in accordance with those of citreoviridin, by the large coupling

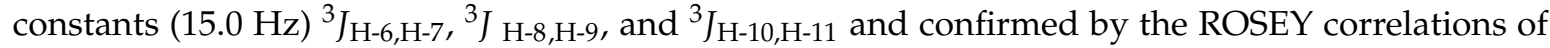
$\mathrm{H}-7 / \mathrm{H}-9, \mathrm{H}-8 / \mathrm{H}-10$, and $\mathrm{H}-9 / \mathrm{H}-11$. In addition, the relative configuration of the tetrahydrofuran ring was determined to be identical with that of citreoviridin by ROESY correlations. The calculated ECD spectrum for 14S,15R,16R,17R-2 matched well with the experimental curve, indicating that 2 possessed the identical absolute configuration with citreoviridin (Figure 4). Consequently, the structure of 2 was determined as 12Z-citreoviridin and named (+)-neocitreoviridin.

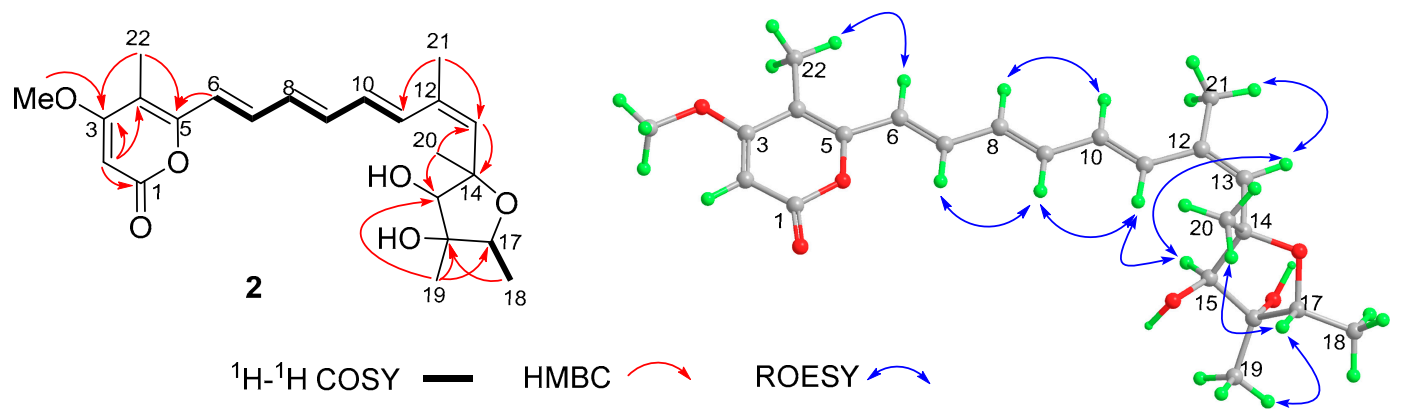

Figure 3. The ${ }^{1} \mathrm{H}-{ }^{1} \mathrm{H}$ COSY and the key HMBC and ROESY correlations of 2.

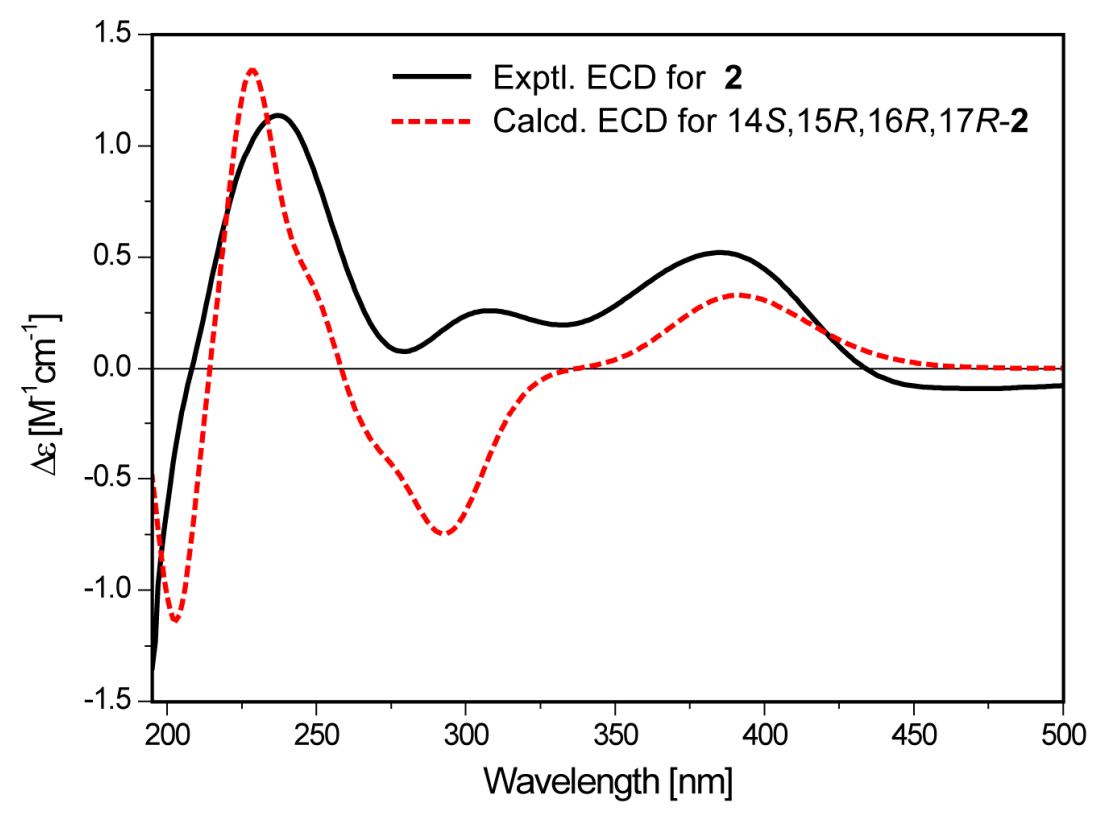

Figure 4. Comparison of the calculated and experimental ECD spectra of 2.

The molecular formula of compound 3 was determined as $\mathrm{C}_{28} \mathrm{H}_{42} \mathrm{O}_{2}$ by HRESIMS. The IR spectrum displayed the absorption bands for the hydroxy $\left(3394 \mathrm{~cm}^{-1}\right)$ and the unsaturated ketone 
$\left(1665 \mathrm{~cm}^{-1}\right)$ groups. Analysis of the ${ }^{1} \mathrm{H}-\mathrm{NMR}$ data revealed the signals for two tertiary methyls at $\delta_{\mathrm{H}} 0.80\left(\mathrm{~s}, \mathrm{H}_{3}-18\right)$ and $1.14\left(\mathrm{~s}, \mathrm{H}_{3}-19\right)$; three secondary methyls at $\delta_{\mathrm{H}} 0.99\left(\mathrm{~d}, \mathrm{H}_{3}-21\right), 1.03\left(\mathrm{~d}, \mathrm{H}_{3}-27\right)$, and $1.04\left(\mathrm{~d}, \mathrm{H}_{3}-26\right)$; two terminal olefinic protons at $\delta_{\mathrm{H}} 4.73(\mathrm{~d}, J=1.8 \mathrm{~Hz}, \mathrm{H}-28 \mathrm{a})$ and $4.68(\mathrm{~d}, J=1.8 \mathrm{~Hz}$, $\mathrm{H}-28 \mathrm{~b})$; and one oxymethine proton at $\delta_{\mathrm{H}} 3.67(\mathrm{H}-3)$. The ${ }^{13} \mathrm{C}-\mathrm{NMR}$ and DEPT spectra revealed 28 carbon resonances that were ascribed to five methyls, 10 methylenes (with one olefinic carbon at $\delta_{C}$ 106.1), six methines (including a cone oxygenated carbon at $\delta_{C} 69.9$ and one $\mathrm{sp}^{2}$ carbon at $\delta_{C} 126.6$ ), and seven nonprotonated carbons (with one carbonyl at $\delta_{C} 197.5$ and four sp ${ }^{2}$ carbons at $\delta_{C} 127.1,141.3$, 156.7, and 165.2). These NMR data were similar to those of ergosta-24(28)-ene-3-ol derivatives [13], suggesting an ergostane skeleton for 3.

Analysis of the COSY data revealed the presence of four partial structures as illustrated by the bold lines in Figure 5. These partial structures were connected by the HMBC correlations from $\mathrm{H}_{3}-19$ to $\mathrm{C}-1, \mathrm{C}-5, \mathrm{C}-9$, and C-10; from $\mathrm{H}_{3}-18$ to C-12, C-13, C-14, and C-17; and from H-15 to C-8 and C-13. The HMBC correlations of $\mathrm{H}_{3}-26$ and $\mathrm{H}_{3}-27$ with $\mathrm{C}-24\left(\delta_{\mathrm{C}} 156.7\right)$ and $\mathrm{H}-25, \mathrm{H}-23 \mathrm{a}$, and $\mathrm{H}-23 \mathrm{~b}$ with C-28 $\left(\delta_{C} 106.1\right)$ allowed the placement of one double bond at C-24 (C-28). The two carbon signals at $\delta_{C} 127.1$ and 165.2 were allocated to C-8 and C-9 double bonds based on the HMBC correlations of $\mathrm{H}_{3}-19$ with $\mathrm{C}-9\left(\delta_{\mathrm{C}} 165.2\right)$ and $\mathrm{H}-11 \mathrm{a}$ and $11 \mathrm{~b}$ with $\mathrm{C}-8\left(\delta_{\mathrm{C}} 127.1\right)$ and C-9. Further correlations of $\mathrm{H}_{3}-18$ with $\mathrm{C}-14\left(\delta_{\mathrm{C}} 141.3\right)$ and $\mathrm{H}-16 \mathrm{a}$ and $\mathrm{H}-16 \mathrm{~b}$ with $\mathrm{C}-14$ and $\mathrm{C}-15\left(\delta_{\mathrm{C}} 126.6\right)$ revealed the third double bond at C-14(C-15). HMBC correlations were observed from H-5, H-6a, and H-6b to the carbonyl carbon $\left(\delta_{C} 197.5\right)$, locating a ketone group at C-7. Finally, HMBC correlations of $\mathrm{H}_{2}-1, \mathrm{H}_{2}-2$, and $\mathrm{H}_{2}-4$ with $\mathrm{C}-3\left(\delta_{\mathrm{C}} 69.9\right)$ allowed the assignment of an $\mathrm{OH}$ group at $\mathrm{C}-3$, completing the full planar structure for 3 . The relative configuration of 3 was established by analysis of the coupling constants and ROESY data. The large coupling constants of $J_{\mathrm{H}-2 \mathrm{~b}, \mathrm{H}-3}(11.4 \mathrm{~Hz})$ and $J_{\mathrm{H}-3, \mathrm{H}-4 \mathrm{~b}}(11.4 \mathrm{~Hz})$ and the ROESY correlations of H-5 with H-3 and H-6a indicated the $\alpha$ - (axial) orientation for H-3, H-5, and H-6a. On the other hand, ROESY correlations of $\mathrm{H}_{3}-19$ with $\mathrm{H}-6 \mathrm{~b}$ and $\mathrm{H}-11 \mathrm{~b}$ and of $\mathrm{H}_{3}-18$ with $\mathrm{H}-11 \mathrm{~b}$ and $\mathrm{H}-20$ revealed these protons on the opposite side. Thus, the structure of 3 was determined as 3 $\beta$-hydroxyergosta-8,14,24(28)-trien-7-one.

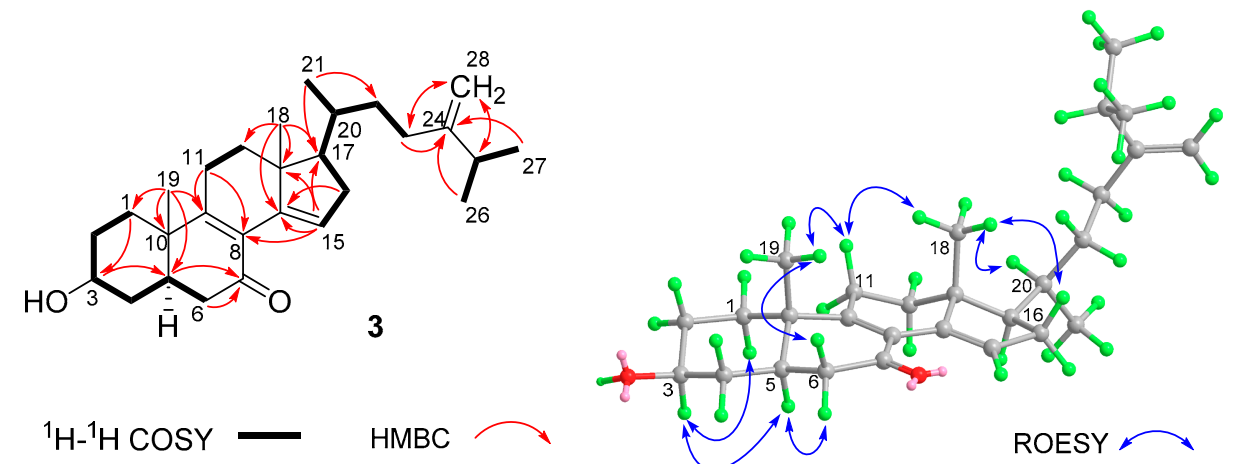

Figure 5. The ${ }^{1} \mathrm{H}-{ }^{1} \mathrm{H}$ COSY and key HMBC and ROESY correlations of 3.

Compounds 1-8 were evaluated for their antiviral activities against HIV-1, influenza A virus (IAV), and HCV (Table 2). Of the tested compounds, compound 1 exhibited inhibitory activities against HIV-1 and $\mathrm{HCV}$ with $\mathrm{IC}_{50}$ values of 4.6 and $7.7 \mu \mathrm{M}$, respectively. Compound 2 showed significant inhibitory activity against IAV with an $\mathrm{IC}_{50}$ value of $3.6 \mu \mathrm{M}$ as compared to $15.4 \mu \mathrm{M}$ of the positive control ribavirin. Compound 3 showed anti-HIV activity with an $\mathrm{IC}_{50}$ of $3.5 \mu \mathrm{M}$ and potent anti-IAV activity with an $\mathrm{IC}_{50}$ of $0.5 \mu \mathrm{M}, 300$-fold stronger than ribavirin. Compounds 4-6 were inactive against the above viruses at the concentration of $10 \mu \mathrm{M}$. It is interesting to note that the other ergostane derivatives, 7 and 8 , showed no detectable inhibitory activity against IAV $\left(\mathrm{IC}_{50}>10 \mu \mathrm{M}\right)$. A recent study by Ge et al. [26] showed that the ergostane derivative, $(20 S, 24 R)$-3 $\beta, 20$-dihydroxyergostan-5(6)-en-7,16-dione (amotsterol D), which was effective against wild-type and multi-drug resistant HIV-1 in the low micromolar range, might target the host cell kinases PKM2, a rate-limiting enzyme of glycolysis, to inhibit replication of HIV-1. Host cell kinases are vital for the replication of a number of viruses and might be targets 
for broad-spectrum antivirals $[27,28]$. Due to the close structural similarity with amotsterol D, it was likely that compound 3 exerted broad-spectrum antiviral activity by the same target. Helicobacter pylori is a Gram-negative pathogen whose infection has been recognized as the causative factor of chronic gastritis, peptic ulceration, and gastric malignancies [29]. In the antibacterial assay, compounds 1 and 2 showed significant antibacterial activities against clinically isolated $H$. pylori (including the drug-sensitive strain G27 and the drug-resistant strain 159) with minimum inhibitory concentrations (MICs) of 1-16 $\mu \mathrm{g} / \mathrm{mL}$, whereas they were inactive against Gram-positive Staphylococcus aureus and Bacillus subtilis and Gram-negative Pseudomonas aeruginosa and Klebsiella pneumoniae (MIC > $128 \mu \mathrm{g} / \mathrm{mL}$ ).

Table 2. Antiviral $\left(\mathrm{IC}_{50}\right.$ and $\left.\mathrm{CC}_{50}, \mu \mathrm{M}\right)$ and antibacterial (MIC, $\mu \mathrm{g} / \mathrm{mL}$ ) activities of compounds 1-3, 7 , and 8 .

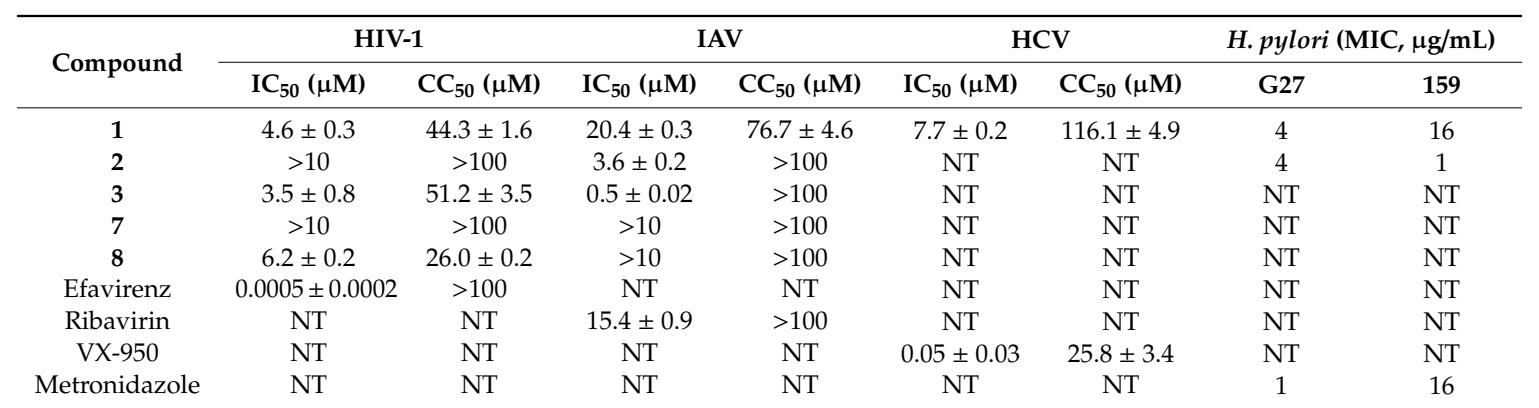

HIV: human immunodeficiency virus; IAV: influenza A virus; HCV: hepatitis C virus; MIC: minimum inhibitory concentration; NT: Not tested.3. Materials and Methods.

\section{Materials and Methods}

\subsection{General Experimental Procedures}

Optical rotations were measured using a Perkin-Elmer model 343 polarimeter (Perkin-Elmer Inc., Waltham, MA, USA). UV and ECD spectra were recorded on an Applied Photophysics Chirascan spectrometer (Applied Photophysics Ltd., Surrey, UK). IR spectra were measured using a Nicolet 5700 FT-IR microscope spectrometer (FT-IR microscope transmission) (Thermo Electron Corp., Madison, WI, USA). NMR spectra were acquired on a AVANCE III HD $600 \mathrm{MHz}$ spectrometers (Bruker Corp., Karlsruhe, Germany) in $\mathrm{CDCl}_{3}$ with tetramethylsilane as an internal reference. ESIMS data were obtained using an Agilent 1100 LC/MSD with a G1956B single quadrupole mass spectrometer (Agilent Technologies, Ltd., Santa Clara, CA, USA). HRESIMS data were recorded using a Thermo LTQ Orbitrap XL mass spectrometer (Thermo Fisher Scientific, Waltham, MA, USA). Flash chromatography was performed on an Ez Purifier (Suzhou Lisure Science Co., Ltd., Suzhou, China). Column chromatography was carried out using silica gel (Qingdao Marine Chemical Inc, Qingdao, China) and Toyopearl gel HW-40F (Tosoh Co., Tokyo, Japan). HPLC separation was performed with a Shimadzu LC-20AP binary pump (Shimadzu Co., Kyoto, Japan) equipped with an SPD-M20A diode array detector using a Shiseido Capcell C18 MGII preparative $(20 \mathrm{~mm} \times 250 \mathrm{~mm})$ or semi-preparative $(10 \mathrm{~mm} \times 250 \mathrm{~mm})$ column.

\subsection{Fungal Material}

The fungus Penicillium sp. IMB17-046 was isolated from marine sediments collected from a mangrove swamp in Sanya, Hainan province, China. The strain was identified as a member of the genus Penicillium by morphological characteristics and sequence analysis. Its $18 \mathrm{~S}$ and ITS-5.8S rDNA gene sequences (GenBank accession no. MK720046 and MK720045) showed the closest match with P. decumbens (GenBank KX553859) and P. manginii (GenBank MH858641) with 99.09\% and 99.48\% sequence similarities, respectively. The strain was deposited in the National Laboratory for Screening Microbial Drug, Institute of Medicinal Biotechnology, Chinese Academy of Medical Sciences. 


\subsection{Fermentation and Isolation}

Penicillium sp. IMB17-046 was cultivated on potato dextrose agar (PDA) plates at $28{ }^{\circ} \mathrm{C}$ for 7 days. Agar cultures were cut into small pieces (about $1 \mathrm{~cm}^{2}$, one piece each) that were inoculated into $500 \mathrm{~mL}$ Fernbach flasks each containing $100 \mathrm{~mL}$ of the potato dextrose broth (PDB) medium ( $3 \mathrm{~g}$ of potato extract, $20 \mathrm{~g}$ of glucose in $1 \mathrm{~L}$ of $\mathrm{H}_{2} \mathrm{O}$ ) and cultured at $28^{\circ} \mathrm{C}$ on a rotary shaker at $200 \mathrm{rpm}$ for 5 days. The resulting seed cultures (each $10 \mathrm{~mL}$ ) were transferred into 30 replicate $500 \mathrm{~mL}$ flasks each containing $100 \mathrm{~mL}$ of the rice medium ( $100 \mathrm{~g}$ of rice, $0.3 \mathrm{~g}$ of peptone in $100 \mathrm{~mL} \mathrm{H}_{2} \mathrm{O}$ ) for 4 weeks at $28^{\circ} \mathrm{C}$. The fungal rice cultures were sequentially extracted with EtOAc $(3 \times 6 \mathrm{~L})$ and $\mathrm{MeOH}(3 \times 6 \mathrm{~L})$. After removing the organic solvent, the residual aqueous extracts were combined and partitioned in $\mathrm{H}_{2} \mathrm{O}$, and extracted with petroleum ether $(5 \times 3 \mathrm{~L})$ and EtOAc $(5 \times 3 \mathrm{~L})$, successively, to give the corresponding extracts. The petroleum ether extracts $(45 \mathrm{~g})$ were subjected to silica gel column chromatography eluting with petroleum ether-EtOAc $(15: 1,10: 1,4: 1,1: 1,0: 1)$ to afford 12 fractions $\left(\mathrm{F}_{1}-\mathrm{F}_{12}\right)$. Fraction $\mathrm{F}_{4}(800 \mathrm{mg})$ was separated on preparative reversed-phase (RP) $\mathrm{C}_{18} \mathrm{HPLC}\left(68 \% \mathrm{MeCN}-\mathrm{H}_{2} \mathrm{O}, 10 \mathrm{~mL} / \mathrm{min}\right)$ and further purified by semi-preparative $\mathrm{HPLC}(77 \% \mathrm{MeOH}, 4 \mathrm{~mL} / \mathrm{min})$ to give 1 (36 mg). Fraction $\mathrm{F}_{5}(650 \mathrm{mg})$ was subjected to RP C18 flash chromatography with gradient elution of $20 \%-100 \% \mathrm{MeOH}-\mathrm{H}_{2} \mathrm{O}$ to afford six subfractions $\left(\mathrm{F}_{5-1}-\mathrm{F}_{5-6}\right)$. Subfraction $\mathrm{F}_{5-4}(300 \mathrm{mg})$ was subjected to preparative RP C18 HPLC $\left(80 \% \mathrm{MeCN}-\mathrm{H}_{2} \mathrm{O}, 10 \mathrm{~mL} / \mathrm{min}\right)$ to yield $3(20 \mathrm{mg})$. Fraction $\mathrm{F}_{7}(220 \mathrm{mg})$ was separated by preparative RP C18 HPLC (50\% MeCN-H $\left.\mathrm{H}_{2} \mathrm{O}, 10 \mathrm{~mL} / \mathrm{min}\right)$ and further purified by semi-preparative HPLC (70\% $\left.\mathrm{MeOH}-\mathrm{H}_{2} \mathrm{O}, 4 \mathrm{~mL} / \mathrm{min}\right)$ to yield $2(20 \mathrm{mg})$. Purities of compounds $1(>96 \%), 2(>96 \%)$, and $3(>97 \%)$ were determined by HPLC-DAD and verified by ${ }^{1} \mathrm{H}-\mathrm{NMR}$ analysis.

Trypilepyrazinol (1): Colorless plate crystal; $[\alpha]_{\mathrm{D}}^{20}+8.6($ c $0.41, \mathrm{MeOH}) ; \mathrm{UV}(\mathrm{MeOH}) \lambda_{\max }(\log \varepsilon)$ 221 (4.68), 281 (3.75), 325 (3.85), 368 (3.56) nm; ECD (c $\left.2.0 \times 10^{-4} \mathrm{M}, \mathrm{MeOH}\right) \lambda_{\max }(\Delta \varepsilon) 206(-0.49)$, 237 (+0.14), 265 (-0.04), 324 (+0.37) nm; IR $v_{\max } 3421,2966,2936,1642,1615,1520,1467,1413,1167$, 1023, and $744 \mathrm{~cm}^{-1} ;{ }^{1} \mathrm{H}-\mathrm{NMR}\left(\mathrm{CDCl}_{3}, 600 \mathrm{MHz}\right)$ and ${ }^{13} \mathrm{C}-\mathrm{NMR}\left(\mathrm{CDCl}_{3}, 150 \mathrm{MHz}\right)$, Table 1; HRESIMS: $m / z 312.1696[\mathrm{M}+\mathrm{H}]^{+}$(calcd for $\mathrm{C}_{18} \mathrm{H}_{22} \mathrm{~N}_{3} \mathrm{O}_{2}, 312.1707$ ).

(+)-Neocitreoviridin (2): Yellow powder; $[\alpha]_{\mathrm{D}}^{20}+67.3(c$ 0.4, $\mathrm{MeOH}) ; \mathrm{UV}(\mathrm{MeOH}) \lambda_{\max }(\log \varepsilon) 235$ (4.06), 291 (4.30), 390 (4.50) nm; ECD (c $\left.6.2 \times 10^{-4} \mathrm{M}, \mathrm{MeOH}\right) \lambda_{\max }(\Delta \varepsilon) 237(+1.14), 308(+0.26)$, 385 (+0.52) nm; IR $v_{\max } 3406,2934,1686,1624,1590,1537,1455,1406,1251,1094,995$, and $803 \mathrm{~cm}^{-1}$; ${ }^{1} \mathrm{H}-\mathrm{NMR}\left(\mathrm{CDCl}_{3}, 600 \mathrm{MHz}\right)$ and ${ }^{13} \mathrm{C}-\mathrm{NMR}\left(\mathrm{CDCl}_{3}, 150 \mathrm{MHz}\right)$, Table 1; HRESIMS: $\mathrm{m} / z$ $403.2106[\mathrm{M}+\mathrm{H}]^{+}$ (calcd for $\mathrm{C}_{23} \mathrm{H}_{31} \mathrm{O}_{6}, 403.2115$ ).

$3 \beta$-Hydroxyergosta-8,14,24(28)-trien-7-one (3): White, amorphous powder; $[\alpha]_{\mathrm{D}}^{20}-4.0(c 0.43, \mathrm{MeOH})$; $\mathrm{UV}(\mathrm{MeOH}) \lambda_{\max }(\log \varepsilon) 297$ (3.43) nm; ECD $\left(c 6.1 \times 10^{-4} \mathrm{M}, \mathrm{MeOH}\right) \lambda_{\max }(\Delta \varepsilon) 211(-6.78), 247(+1.44)$, 285 (-1.52), 336 (+0.35) nm; IR $v_{\max } 3394,2925,1665,1650,1467,1377$, and $1041 \mathrm{~cm}^{-1} ;{ }^{1} \mathrm{H}-\mathrm{NMR}\left(\mathrm{CDCl}_{3}\right.$, $600 \mathrm{MHz})$ and ${ }^{13} \mathrm{C}-\mathrm{NMR}\left(\mathrm{CDCl}_{3}, 150 \mathrm{MHz}\right)$, Table 1 ; HRESIMS: $m / z 411.3258[\mathrm{M}+\mathrm{H}]^{+}$(calcd for $\mathrm{C}_{28} \mathrm{H}_{43} \mathrm{O}_{2}$, 411.3258).

\subsection{Crystallographic Analysis of 1}

A colorless plate crystal of 1 was obtained from $\mathrm{CHCl}_{3}-\mathrm{MeOH}(9: 1 v / v)$ via slow evaporation. The crystal data were obtained at $293 \mathrm{~K}$ using $\mathrm{Cu} \mathrm{K}$ radiation (1.54184 A) on an Oxford Diffraction Gemini Ultra CCD diffractometer. The structure was solved by direct methods (SHELXS-97) and refined with the SHELXL-97 refinement package using Least Squares minimization [30]. Crystal data of 1 was deposited in the Cambridge Crystallographic Data Centre with the deposition number CCDC 1935589. CCDC 1935589 contains the supplementary crystallographic data for this paper. These data can be obtained free of charge via http://www.ccdc.cam.ac.uk/conts/retrieving.html (or from the CCDC, 12 Union Road, Cambridge CB2 1EZ, UK; Fax: +44 1223 336033; E-mail: deposit@ccdc.cam.ac.uk).

Crystal data of $1: 2\left(\mathrm{C}_{18} \mathrm{H}_{21} \mathrm{~N}_{3} \mathrm{O}_{2}\right), \mathrm{M}=622.75$, monoclinic, space group $\mathrm{C} 2, \mathrm{a}=21.9518(3) \AA$, $\mathrm{b}=6.1592(1) \AA, \mathrm{c}=25.3607(3) \AA, \alpha=90^{\circ}, \beta=102.5169(13)^{\circ}, \gamma=90^{\circ}, \mathrm{V}=3347.43(8) \AA 3 . \mathrm{Z}=4, \mu(\mathrm{Cu}$ $\mathrm{K} \alpha)=0.659$, Dcalc $=1.236 \mathrm{~g} / \mathrm{cm}^{3} ; 13396$ reflections measured in the range of $4.0940^{\circ} \leq \theta \leq 66.5790^{\circ}, 5664$ independent reflections, $R_{\text {int }}=0.0215,424$ parameters, 1 restraints. The final indices were $w R_{2}=0.1076$, 
$R_{1}=0.0372[\mathrm{I}>2 \sigma(I)]$. The goodness of fit on $\mathrm{F}^{2}$ was 1.036 . Flack parameter $\mathrm{x}=0.02(8)$. The Hooft parameter $\mathrm{y}=0.04(7)$.

\subsection{ECD Calculation of $(14 S, 15 R, 16 R, 17 R)-2$}

A conformation search was performed on Spartan 14 software (version 1.1.0, Wavefunction Inc. 2014, Irvine, CA, USA) using the MMFF94 molecular mechanics force field. The obtained conformers within a $4 \mathrm{kcal} / \mathrm{mol}$ upper energy limit were geometry optimized at the B3LYP/6-31+G $(\mathrm{d}, \mathrm{p})$ level in gas using the Gaussian 09 program [31]. The harmonic vibrational frequencies were calculated at the same level to provide their free energy values $(\Delta \mathrm{G})$. The low-energy conformers with $\Delta \mathrm{G} \leq 4.0 \mathrm{kcal} / \mathrm{mol}$ were subjected to further geometry optimization and frequency calculation at the M06-2X/6-311+G(d,p) level with the polarizable continuum model (PCM) in $\mathrm{MeOH}$. The equilibrium population of each conformer at $298.15 \mathrm{~K}$ was calculated according to the $\Delta \mathrm{G}$ obtained by the second-round optimization at the $m 06-2 x / 6-311+G(d, p)$ level. Energies of the conformers with Boltzmann distribution $(>1 \%)$ were calculated using the TDDFT methodology (NStates $=65)$ at the CAM-B3LYP/TZVP level. The ECD spectrum of each conformer was generated by the SpecDis program [32] using a Gaussian function band width $\sigma=0.30 \mathrm{eV}$. The calculated ECD spectrum for $(14 S, 15 R, 16 R, 17 R)-2$ was obtained by averaging the calculated data of each conformer according to their Boltzmann population.

\subsection{Anti-HIV Assay}

Anti-HIV activities were evaluated according to a procedure described previously [33]. Briefly, 293T cells were co-transfected with the vector pNL-luc-E- containing a full-length HIV-1 proviral DNA with a firefly luciferase gene and the vesicular stomatitis virus glycoprotein-expressing vector pHCMV-G. After cultivation for $48 \mathrm{~h}$, the vesicular stomatitis virus glycoprotein (VSV-G) pseudotyped HIV-1 viruses were harvested by filtration. SupT1 cells $\left(1 \times 10^{5}\right)$ were infected with the VSV-G-HIV virus (multiplicity of infection, $\mathrm{MOI}=1$ ) and treated with the test compounds in triplicate. Efavirenz was used as a positive control. After $48 \mathrm{~h}$ inoculation, the SupT1 cells were lysed and the inhibition rate was determined using a firefly Luciferase Assay System (Promega). The concentration of compounds inhibiting $50 \%$ viral replication $\left(\mathrm{IC}_{50}\right.$ ) was calculated by Origin 8.0 (OriginLab Co. Northampton, MA, USA).

\subsection{Anti-Influenza A Virus Assay}

Anti-influenza A virus assays were performed by using the cell-based high-throughput approach [34]. Briefly, 293T-Gluc cells were treated with test compounds and incubated for $2 \mathrm{~h}$ prior to infection. Then, the cells were infected with influenza A/WSN/33 (H1N1) viruses with an MOI of 0.3. After a further $24 \mathrm{~h}$ incubation, the cell supernatant was collected and measured for Gaussia luciferase activity. Ribavirin was used as a positive and negative control.

\subsection{Anti-HCV Assay}

Anti-HCV assays were carried out as described previously [5].

\subsection{Cytotoxicity Assay}

Cytotoxicity of compounds were assayed for the uninfected 293T-Gluc, SupT1, and Huh7.5 cells. 293T-Gluc and Huh7.5 cells were cultured in Dulbecco's modified Eagle's medium supplemented with 10\% fetal bovine serum (FBS, Invitrogen). SupT1 cells were cultured in RPMI1640 medium supplemented with $10 \%$ FBS. Various concentrations of test compounds ( $1 \mu \mathrm{L}$ each well) were added to the 293T-Gluc and SupT1 cells $\left(1 \times 10^{5}\right.$ cells/well) in 96-well plates. After incubation at $37^{\circ} \mathrm{C}$ for $48 \mathrm{~h}, 10 \mu \mathrm{L}$ of CCK-8 reagent was added to the cells and they were incubated for another $4 \mathrm{~h}$. Then, the absorbance of each well was recorded at $450 \mathrm{~nm}$. A cytotoxicity assay for Huh7.5 cells was 
carried out using the MTT method as described previously [5]. The $50 \%$ cytotoxicity concentration $\left(\mathrm{CC}_{50}\right)$ was calculated by Origin 8.0 software.

\subsection{Antibacterial Assay}

The antibacterial activities against $H$. pylori, S. aureus, B. subtilis, P. aeruginosa, and K. pneumonia were assayed by examining the MIC using the broth micro-dilution method as previously described [5,35].

\section{Conclusions}

In summary, three new natural products, trypilepyrazinol (1), (+)-neocitreoviridin (2), and 3 $\beta$-hydroxyergosta-8,14,24(28)-trien-7-one (3) were identified from the solid cultures of the mangrove-derived Penicillium sp. IMB17-046. Compounds 1 and 3 showed broad-spectrum antiviral properties against different types of viruses while $\mathbf{2}$ displayed significant antibacterial activity against H. pylori as well as an anti-IAV effect. Trypilepyrazinol (1) is characterized by a pyrazine motif. Pyrazine heterocycle is an important pharmacophore present as a basic scaffold in various clinical drugs with a wide range of pharmacological and therapeutic activities, such as antitumor, anti-inflammatory, antithrombotic, anti-diabetic, and anti-tubercular [36,37]. However, natural products containing a pyrazine moiety are relatively rare [19]. To the best of our knowledge, trypilepyrazinol (1) is the first example of natural pyrazines exhibiting broad-spectrum antiviral activities and antibacterial activity against $H$. pylori.

Supplementary Materials: The Supplementary Materials are available online.

Author Contributions: Conceptualization, M.G., C.X., S.C., and Z.P.; Methodology, J.L. and Y.W.; Validation, X.H. and S.L.; Formal analysis, M.G. and J.L.; Investigation, J.L., Y.W., Y.G., S.L., and J.J.; Resources, M.G., C.X., H.B., Z.P., and S.C.; Writing —original draft preparation, M.G. and J.L.; Writing—review and editing, M.G.; Project administration, M.G.; Funding acquisition, M.G.

Funding: This work was financially supported by the National Natural Science Foundation of China (Grant no. 81872781), CAMS Innovation Fund for Medical Sciences (CIFMS, 2016-I2M-2-002), and the Drug Innovation Major Project of China (Grant no. 2018ZX09711001-007-002).

Conflicts of Interest: The authors declare no conflict of interest.

\section{References}

1. Global Hepatitis Report; World Health Organization: Geneva, Switzerland, 2017.

2. De Clercq, E.; Li, G. Approved antiviral drugs over the past 50 years. Clin. Microbiol. Rev. 2016, 29, 695-747. [CrossRef] [PubMed]

3. Rateb, M.E.; Ebel, R. Secondary metabolites of fungi from marine habitats. Nat. Prod. Rep. 2011, 28, 290-344. [CrossRef] [PubMed]

4. Mayer, A.M.S.; Rodríguez, A.D.; Taglialatela-Scafati, O.; Fusetani, N. Marine pharmacology in 2012-2013: Marine compounds with antibacterial, antidiabetic, antifungal, anti-inflammatory, antiprotozoal, antituberculosis, and antiviral activities; affecting the immune and nervous systems, and other miscellaneous mechanisms of action. Mar. Drugs 2017, 15, 273. [CrossRef]

5. Li, J.; Hu, Y.; Hao, X.; Tan, J.; Li, F.; Qiao, X.; Chen, S.; Xiao, C.; Chen, M.; Peng, Z.; et al. Raistrickindole A, an anti-HCV oxazinoindole alkaloid from Penicillium raistrickii IMB17-034. J. Nat. Prod. 2019, 82, 1391-1395. [CrossRef] [PubMed]

6. Hu, Y.; Wang, M.; Wu, C.; Tan, Y.; Li, J.; Hao, X.; Duan, Y.; Guan, Y.; Shang, X.; Wang, Y.; et al. Identification and proposed relative and absolute configurations of niphimycins $\mathrm{C}-\mathrm{E}$ from the marine-derived Streptomyces sp. IMB7-145 by genomic analysis. J. Nat. Prod. 2018, 81, 178-187. [CrossRef] [PubMed]

7. Wang, Q.; Zhang, Y.; Wang, M.; Tan, Y.; Hu, X.; He, H.; Xiao, C.; You, X.; Wang, Y.; Gan, M. Neo-actinomycins A and B, natural actinomycins bearing the $5 \mathrm{H}$-oxazolo[ $[4,5-b]$ phenoxazine chromophore, from the marine-derived Streptomyces sp. IMB094. Sci. Rep. 2017, 7, 3591. [CrossRef] [PubMed] 
8. Tan, Y.; Hu, Y.; Wang, Q.; Zhou, H.; Wang, Y.; Gan, M. Tetrocarcins N and O, glycosidic spirotetronates from a marine-derived Micromonospora sp. identified by PCR-based screening. RSC Advances 2016, 6, 91773-91778. [CrossRef]

9. Wu, C.; Tan, Y.; Gan, M.; Wang, Y.; Guan, Y.; Hu, X.; Zhou, H.; Shang, X.; You, X.; Yang, Z.; et al. Identification of elaiophylin derivatives from the marine-derived actinomycete Streptomyces sp. 7-145 using PCR-based screening. J. Nat. Prod. 2013, 76, 2153-2157. [CrossRef]

10. Nishiyama, S.; Shizuri, Y.; Toshima, H.; Ozaki, M.; Yamamura, S.; Kawai, K.; Kawai, N.; Furukawa, H. Isolation, structural elucidation, and total synthesis of epiisocitreoviridinol. Chem. Lett. 1987, 16, 515-518. [CrossRef]

11. Asai, T.; Luo, D.; Yamashita, K.; Oshima, Y. Structures and biomimetic synthesis of novel $\alpha$-pyrone polyketides of an endophytic Penicillium sp. In catharanthus roseus. Org. Lett. 2013, 15, 1020-1023. [CrossRef]

12. Muhammad, I.; Choudhary, S.G.M. Talat Mukhmoor, Farzana Shaheen, Shamsher Ali, and Atta-ur-Rahman. Isolation of bioactive compounds from Aspergillus terreus. Z. Naturforsch. 2004, 59b, 324-328.

13. Cui, C.M.; Li, X.M.; Meng, L.; Li, C.S.; Huang, C.G.; Wang, B.G. 7-nor-ergosterolide, a pentalactone-containing norsteroid and related steroids from the marine-derived endophytic Aspergillus ochraceus EN-31. J. Nat. Prod. 2010, 73, 1780-1784. [CrossRef]

14. Piccialli, V.; Sica, D. Four new trihydroxylated sterols from the sponge Spongionella gracilis. J. Nat. Prod. 1987, 50, 915-920. [CrossRef]

15. Motohashi, K.; Inaba, K.; Fuse, S.; Doi, T.; Izumikawa, M.; Khan, S.T.; Takagi, M.; Takahashi, T.; Shin-ya, K. JBIR-56 and JBIR-57, 2(1H)-pyrazinones from a marine sponge-derived Streptomyces sp. SPD081030SC-03. J. Nat. Prod. 2011, 74, 1630-1635. [CrossRef]

16. Goetz, M.A.; Zhang, C.; Zink, D.L.; Arocho, M.; Vicente, F.; Bills, G.F.; Polishook, J.; Dorso, K.; Onishi, R.; Gill, C.; et al. Coelomycin, a highly substituted 2,6-dioxo-pyrazine fungal metabolite antibacterial agent discovered by Staphylococcus aureus fitness test profiling. J. Antibiot. 2010, 63, 512-518. [CrossRef]

17. Flack, H.D. On enantiomorph-polarity estimation. Acta Crystallogr. Sect. A 1983, 39, 876-881. [CrossRef]

18. Hooft, R.W.W.; Straver, L.H.; Spek, A.L. Determination of absolute structure using Bayesian statistics on Bijvoet differences. J. Appl. Crystallogr. 2008, 41, 96-103. [CrossRef]

19. Badrinarayanan, S.; Sperry, J. Pyrazine alkaloids via dimerization of amino acid-derived alpha-amino aldehydes: Biomimetic synthesis of 2,5-diisopropylpyrazine, 2,5-bis(3-indolylmethyl)pyrazine and actinopolymorphol C. Org. Biomol. Chem. 2012, 10, 2126-2132. [CrossRef]

20. Nawrath, T.; Dickschat, J.S.; Kunze, B.; Schulz, S. The biosynthesis of branched dialkylpyrazines in myxobacteria. Chem. Biodivers. 2010, 7, 2129-2144. [CrossRef]

21. Franck, B.; Gehrken, H.P. Citreoviridins from Aspergillus terreus. Angew. Chem. Int. Ed. Engl. 1980, 19, 461-462. [CrossRef]

22. Steyn, P.S.; Vleggaar, R.; Wessels, P.L.; Woudenberg, M. Biosynthesis of citreoviridin. A carbon-13 N.M.R. Study. J. Chem. Soc. Perkin Trans. 1 1982, 2175-2178. [CrossRef]

23. Sakabe, N.; Goto, T.; Hirata, Y. Structure of citreoviridin, a mycotoxin produced by Penicillium citreo-viride molded on rice. Tetrahedron 1977, 33, 3077-3081. [CrossRef]

24. Arai, K.; Masuda, K.; Kiriyama, N.; Nitta, K.; Yamamoto, Y.; Shimizu, S. Metabolic products of Aspergillus terreus. IV. Metabolites of the strain ifo 8835. (2). The isolation and chemical structure of indolyl benzoquinone pigments. Chem. Pharm. Bull. 1981, 29, 961-969. [CrossRef]

25. Nagel, D.W.; Steyn, P.S.; Scott, D.B. Production of citreoviridin by Penicillium pulvillorum. Phytochemistry 1972, 11, 627-630. [CrossRef]

26. Ge, Y.Z.; Zhou, B.; Xiao, R.X.; Yuan, X.J.; Zhou, H.; Xu, Y.C.; Wainberg, M.A.; Han, Y.S.; Yue, J.M. A new class of HIV-1 inhibitors and the target identification via proteomic profiling. Sci. China Chem. 2018, 61, 1430-1439. [CrossRef]

27. Perwitasari, O.; Yan, X.; O’Donnell, J.; Johnson, S.; Tripp, R.A. Repurposing kinase inhibitors as antiviral agents to control influenza A virus replication. Assay Drug Dev. Technol. 2015, 13, 638-649. [CrossRef]

28. Mohr, E.L.; McMullan, L.K.; Lo, M.K.; Spengler, J.R.; Bergeron, É.; Albariño, C.G.; Shrivastava-Ranjan, P.; Chiang, C.-F.; Nichol, S.T.; Spiropoulou, C.F.; et al. Inhibitors of cellular kinases with broad-spectrum antiviral activity for hemorrhagic fever viruses. Antiviral Res. 2015, 120, 40-47. [CrossRef]

29. Fock, K.M.; Graham, D.Y.; Malfertheiner, P. Helicobacter pylori research: Historical insights and future directions. Nat. Rev. Gastroenterol. Hepatol. 2013, 10, 495. [CrossRef] 
30. Sheldrick, G.M. A short history of shelx. Acta Crystallogr. Sect. A 2008, 64, 112-122. [CrossRef]

31. Frisch, M.J.; Trucks, G.W.; Schlegel, H.B.; Scuseria, G.E.; Robb, M.A.; Cheeseman, J.R.; Scalmani, G.; Barone, V.; Mennucci, B.; Petersson, G.A.; et al. Gaussian 09, Revision a.1; Gaussian, Inc.: Wallingford, CT, USA, 2009.

32. Bruhn, T.; Schaumlöffel, A.; Hemberger, Y.; Bringmann, G. Specdis: Quantifying the comparison of calculated and experimental electronic circular dichroism spectra. Chirality 2013, 25, 243-249. [CrossRef]

33. Ding, J.; Zhao, J.; Yang, Z.; Ma, L.; Mi, Z.; Wu, Y.; Guo, J.; Zhou, J.; Li, X.; Guo, Y.; et al. Microbial natural product alternariol 5-O-methyl ether inhibits HIV-1 integration by blocking nuclear import of the pre-integration complex. Viruses 2017, 9, 105. [CrossRef]

34. Gao, Q.; Wang, Z.; Liu, Z.; Li, X.; Zhang, Y.; Zhang, Z.; Cen, S. A cell-based high-throughput approach to identify inhibitors of influenza A virus. Acta. Pharm. Sin. B 2014, 4, 301-306. [CrossRef]

35. Huang, Y.; Hang, X.; Jiang, X.; Zeng, L.; Jia, J.; Xie, Y.; Li, F.; Bi, H. In vitro and in vivo activities of zinc linolenate, a selective antibacterial agent against Helicobacter pylori. Antimicrob. Agents Chemother. 2019, 63. [CrossRef]

36. Miniyar, P.B.; Murumkar, P.R.; Patil, P.S.; Barmade, M.A.; Bothara, K.G. Unequivocal role of pyrazine ring in medicinally important compounds: A review. Mini. Rev. Med. Chem. 2013, 13, 1607-1625. [CrossRef]

37. Dolezal, M.; Zitko, J. Pyrazine derivatives: A patent review (june 2012-present). Expert Opin. Ther. Pat. 2015, 25, 33-47. [CrossRef]

Sample Availability: Samples of the compounds 1-8 are available from the authors. 